\title{
Exporter Price Response to Exchange Rate Changes
}

\author{
Fosse, Henrik Barslund
}

Document Version

Final published version

Publication date:

2012

\section{License \\ CC BY-NC-ND}

Citation for published version (APA):

Fosse, H. B. (2012). Exporter Price Response to Exchange Rate Changes. Centre for Economic and Business Research, Copenhagen Business School.

Link to publication in CBS Research Portal

\section{General rights}

Copyright and moral rights for the publications made accessible in the public portal are retained by the authors and/or other copyright owners and it is a condition of accessing publications that users recognise and abide by the legal requirements associated with these rights.

\section{Take down policy}

If you believe that this document breaches copyright please contact us (research.lib@cbs.dk) providing details, and we will remove access to the work immediately and investigate your claim. 


\title{
Exporter Price Response to Exchange Rate Changes
}

BY

\author{
HENRIK BARSLUNd Fosse
}

June 2012

ABSTRACT: Firms exporting to foreign markets face a particular challenge: to price their exports in a foreign market when the exchange rate changes. This paper takes on pricingto-market using a unique data set that covers firm level monthly trade at great detail. As opposed to annual trade flows, monthly trade flows bring us closer to the transaction level where firm decisions are actually made. I find that the utilization of monthly data does add new information about the average level of pricing-to-market, and the differences between long-run pricing-to-market and short-run pricing-to-market. Furthermore, I find industry differences in pricing-to-market in terms of the magnitude (zero to complete pricing-to-market) and the timing (when do firms changes prices), and that pricing-to-market is stronger on high-income markets. As discussed in detail in the paper, all results are in-line with predictions of several theoretical contributions to the litterature on pricing-to-market and exchange rate pass-through.

JEL Codes: F14, F31, L11

KEYWORDs: Pricing-to-market, heterogeneous exporters, monthly firm level trade data

Correspondance: hf.eco@cbs.dk. Henrik Barslund Fosse, CEBR at Department of Economics.

Acknowledgments: Special thanks to Pascalis Raimondos-Møller, Lisbeth la Cour, and Jan Rose Skasen. Financial support from the Danish Social Science Research Council and data provided by the Centre for Economic and Business Research is gratefully acknowledged. 


\section{INTRODUCTION}

Firms exporting to foreign markets face a particular challenge: to price their exports in a foreign market when the exchange rate changes. These export sales are influenced when the exchange rate changes and thus adjusting prices in response to these changes is crucial. If firms respond to fluctuations in foreign currencies by changing their export prices, we say that firms are pricingto-market (PTM). Whether firms adjust prices or not, and by how much, depends on a range of circumstances, and in particular how competitive product markets are. The discussion of PTM relates to the long-standing literature on incomplete exchange rate pass-through ${ }^{1}$ that is concerned with why import prices do not fully adjust to exchange rate changes.

This paper takes on PTM using a unique data set that covers firm level trade at great detail at monthly frequency. These high frequent data offer the opportunity of a new view on what hides behind the time-aggregate estimates typically found using annual data. Annual trade flows are the sum of multiple decisions taken at different points in time. By moving to monthly trade flows we get closer to the transaction level where firm decisions are actually made. To see the benefit of that, note that annual data provide annual unit values - called prices in this literature. By being annual data, these prices are averages over the different prices the firm has charged during that year. With quantity rebates being a popular pricing strategy (for recent evidence see e.g. Chu, Leslie \& Sorensen, 2011), annual averages may indeed be far away from actual prices. Using monthly data, and thus monthly unit values, we can be almost sure that unit values are indeed close to the price specified in a particular export contract.

I find that the utilization of monthly data does add new information about average PTM, and the differences between long-run PTM (LRPTM) $)^{2}$ and short-run PTM (SRPTM) $)^{3}$. Furthermore, I find industry differences in terms of the magnitude and the timing of PTM, and that PTM is stronger on high-income markets. As discussed in detail later on in the paper, these results are in-line with theoretical predictions of choice of invoice currency and the associated pricing mechanism.

My analysis is performed using the unique opportunity of matching the population of Danish firms from the FIDA panel from Statistics Denmark with monthly firm-product-destination level trade flows. I match the firm-level data with foreign exchange rate data from 27 non-euro

\footnotetext{
${ }^{1}$ The literature on exchange rate pass-through has been around for the past three decades. Goldberg \& Knetter (1997), Campa \& Goldberg (2005), and Gopinath \& Itskhoki (2010) represent important papers from each decade.

${ }^{2}$ Defined as the sum of exchange rate impact from 12 monthly lags.

${ }^{3}$ Defined as impact from a significant single lag of the exchange rate.
} 
countries that make up about half of all Danish manufacturing exports. The data allows me to estimate closely the link between high-frequency firm-level trade and the constantly changing exchange rate. ${ }^{4}$ I estimate implied price elasticities to the exchange rate from a set of fixed effects (within) regressions.

Following Berman, Martin \& Mayer (2012) this paper starts by estimating export price elasticities using annual data on Danish firms. These annual estimates are computed in order to later on contrast the estimates using the more frequent monthly data. Using this annual data I find that Danish exporters on average adjust local currency export prices by $1.4 \%$ following a $10 \%$ currency change (i.e. PTM is 14\%). Such an elasticity resembles the one found in the French annual firm-product-destination-level data. ${ }^{5}$ But what exactly does this annual PTM measure cover? Is it a time-averaged measure or a long-run effect? Following Campa \& Goldberg (2005), I sort out the possible time-aggregation by comparing the annual estimates to different estimates from the monthly data: specifically LRPTM and SRPTM. I find that overall LRPTM in the manufacturing sector is $18 \%$, thus evidence of higher PTM than the annual estimate suggest. From the estimation equation for the $\mathrm{LRPTM}^{6}$, I restrict the estimation to as few lags possible in search of a short-run estimate for PTM. At the aggregate level I find that SRPTM prevails in the very short run and on average the value coincides with the LRPTM estimate. However, restricting the analyses to high-income destination markets points to higher SRPTM. Further exploring SRPTM and LRPTM within industries demonstrates that PTM varies considerably across industries in terms of magnitude and timing, and with large differences between SRPTM and LRPTM.

My results suggest that exporting firms respond to changes of exchange rates by swiftly adjusting their prices as pricing-to-maket considerations imply. As time passes and more information is available concerning competitors' pricing and market reactions, firms will reduce their initial adjustments, and thus the long-run response to exchange rate movements is lower than initial, short-run responses. Clearly, annual data are not in position to uncover such a pattern of responses. Having knowledge on how firms react to exchange rates changes both in the short and the long run is important when assessing exchange rate regimes and their implications for firm behaviour.

\footnotetext{
${ }^{4}$ In contrast, Campa \& Goldberg (2005) use an OECD country-level panel.

${ }^{5}$ Best comparable measure from Berman, Martin \& Mayer (2012) is in the range of 9.7-12.4\%

${ }^{6}$ I follow the traditional definition (see Campa \& Goldberg, 2005, and Gopinath \& Itskhoki, 2010) as described in detail later on
} 
The paper proceeds as follows: Section 2 discusses PTM and contributions to the PTM and pass-through literature. Section 3 presents the data. Section 4 presents the estimation methods. Section 5 presents the results, and section 6 concludes.

\section{Exchange Rates and Trade}

While estimation of PTM focuses on export prices, many studies have focused on import prices and to what extent they respond to exchange rate movements. This literature has documented the presence of incomplete exchange rate pass-through, i.e. that import prices do not fully adjust to exchange rate changes, and thus indirectly evidence of imperfect competition. The discussion in this section will also briefly concern exchange rate pass-through, because contributions to this literature and the finding of incomplete pass-through can be conceived as the mirror image of PTM. When discussing pricing to market I will refer to different elements of pricing-to-market, specifically short-run pricing-to-market (hereafter SRPTM) and long-run pricing-to-market (hereafter LRPTM). In the pass-through literature we also find an equivalent terminology.

The literature on exchange pass-through is well-covered and goes well back in time. Goldberg \& Knetter (1997) document exchange rate pass-through on import prices of $60 \%{ }^{7}$ Recently in the pass-through literature Gopinath \& Itskhoki (2010) present and calibrate a model with price rigidities. The results suggests that long-run pass-through on import prices is much lower $(20 \%)$ than the $60 \%$ Goldberg \& Knetter (1997) suggested. Campa \& Goldberg (2005) document differences in short-run and long-run exchange rate pass-though levels as well as differences across source countries. Though pass-through studies often offer great detail on the product side, they are commonly macro level studies limited to explore industry and country variation, and not firm-level based analyses.

The empirical literature on PTM from the perspective of the firm is vastly unexplored. Berman, Martin \& Mayer (2012) are the first to explore the firm-level analysis of heterogeneous PTM. They provide estimates using French firm-level data and document the heterogeneity of export price elasticities with respect to exchange rate changes. They explain theoretically, and they are able to document, heterogeneity in PTM on the basis of productivity differences. Extending Melitz \& Ottaviano (2008) to include exchange rates they consider product markets to

\footnotetext{
${ }^{7}$ Estimates vary considerably (e.g. 20-25\% in Gopinath, Itskhoki \& Rigobon, 2007). Other papers include: Knetter (1993), Lapham (1995), Feenstra et al (1996). Recent studies include Halpern \& Koren (2007), Gopinath \& Rigobon (2008), Gopinath, Itskhoki \& Rigobon (2007), and Gopinath \& Itskhoki (2010).
} 
have decreasing price elasticities (a feature that e.g. linear demand satisfies) ${ }^{8}$. In this theoretical setting, high-productivity firms have lower prices compared to low-productivity firms. They therefore operate further down the demand curve and perceive demand elasticities for their products to be lower. If an exporter is exposed to a depreciation of its currency, its price in the foreign currency falls if the exporter does not react. This implies complete exchange rate pass-through. If the exporter perceives demand elasticities for its products to be low, then it can withhold some of the currency gain by increasing its price markup, thus increasing its home currency price. This is an act of PTM and implies incomplete exchange rate pass-through.

If entering into exporting involves fixed costs, we have endogenous selection into exporting, implying that observed exporting firms in the data per se are more productive than non-exporters (Melitz, 2003). Thus, from this selection story, we can expect that the average exporter exercises PTM (i.e. we can expect to find significant implied export price elasticities to exchange rates) because these exporters are fairly productive, otherwise they would not export. Moreover, if firms do perceive product price elasticities to be low, and also to be lower for more productive producers, we can expect above average PTM from the most productive exporters compared to the rest of the exporters. Indeed, while Berman, Martin \& Mayer (2012) find evidence of PTM for the average exporter, they also find that less-than-average productive exporters engage less in PTM and that highly productive exporters engage more in PTM.

Performing a similar estimation of average PTM on Danish data shows that evidence of PTM exist among Danish Firms. So Danish firms that have succeeded in exporting, are to some extent competitive and have some level of market power. They can lower product prices less than one-to-one in response to exchange rate appreciations by not fully lowering export prices, and they can raise export prices somewhat in response to exchange rate depreciations and thereby not lower product prices one-to-one on the foreign market.

However, when we take theory to annual data and ultimately claim to test firm reactions, we must state clearly what we are trying to reveal. Annual average of the exchange rate takes out a great deal of variation. For example ${ }^{9}$, for the US dollar against the Danish krone in the period 2004-2006 the three annual averages were within a range of $0.9 \%$ between the lowest and the highest of the averages. So virtually no observations on pricing to market should be made.

\footnotetext{
${ }^{8}$ Berman, Martin \& Mayer (2011) also argue that Atkeson \& Burnstein (2008) and a "firm-heterogeneity" extension Corsetti and Dedola's (2005) model with distribution costs can deliver such variable elasticities across firms.

${ }^{9}$ See Appendix B for more examples.
} 


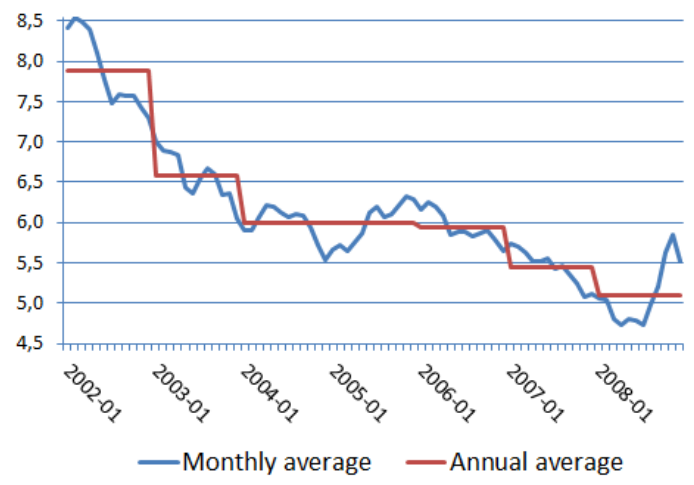

Figure 1: DKK per USD from JAN 2001 to DEC 2008

In this period, however, the monthly average fluctuates from $6 \%$ below the period average to $14 \%$ above the period average. Thus, several observations of considerable magnitude are left out in annual estimations compared to monthly, quarterly or even semi-annual data ${ }^{10}$. Thus, estimation of PTM using annual data does surely not represent a measure of SRPTM. This will also be clear from the results. PTM from annual data more resembles LRPTM, but at best we can consider the annual measure a time-average PTM measure biased towards LRPTM.

Low short-run and high long-run pass-through rates (or equivalently high SRPTM and low LRPTM) are documented empirically by Campa \& Goldberg (2005) and theoretically by Drozd \& Nosal (2012). Drozd \& Nosal suggest a model in which sluggish market expansion in the shortrun induces sellers to fight for market shares more fiercely than in the more flexible long-run where the market expands. ${ }^{11}$

Campa \& Goldberg (2005) using a OECD macro-panel of commodity trade conclude that in the short-run the existence of partial pass-through rejects suggestions of both producer-currencypricing (implying complete pass-through) and local-currency-pricing (zero pass-through). The choice of invoice currency is central in their argumentation. From a theoretical point of view they rely on Devereux \& Engel (2001) and Bacchetta \& Wincoop (2005) who suggest that monetary policy and exchange rate variability influences choice of invoice currency. If the monetary policy of a destination country is stable relative to the firm's own currency, and exchange rate variability is relatively low, then the invoice currency should be the one of your trading partner. ${ }^{12}$ This

\footnotetext{
${ }^{10}$ See table A2 in the appendix.

${ }^{11}$ Fighting for market shares is also implied by Atkeson \& Burstein's (2008) cournot type model.

${ }^{12}$ If country monetary policies are equally stable, one can also argue from a practical point of view that a firm wants to ensure that its products are as easily accessible as possible. It is a burden barrier and a burden for customers to translate foreign currency prices into their own currency and worry about risk.
} 
reasoning implies that we can expect to see that pass-through on high-income markets is low (or equivalently PTM high) compared to mid- and lower-income markets, just because high-income countries are traditionally more stable from a monetary point of view.

With this overview in mind, we have multiple suggestions as to why the distinction between SRPTM and LRPTM is worth investigating, and why PTM is expected to be stronger on highincome markets. To investigate these issues, I rely on detailed, high-frequent export data from Denmark which are presented in the next section.

\section{DATA}

I use the FIDA panel from Statistics Denmark. The data cover the universe of Danish firms from 1996 to 2008 and close to $100 \%$ of Denmark's external trade. The analysis takes place at the firm-product-destination-time level. I limit, however, the set of products per firm to only cover the best selling product at each destination at each point in time. ${ }^{13}$ The panel consists of manufacturing firms exporting to non-euro countries that have more than 10 million DKK in export sales per year (about $€ 1.4$ million). The summary statistics of the annual and monthly data sets are presented in table 1 . The resulting panel has 2,567 firms, 6,407 products and 653,604 observations (firm-product-country-time) between OCT 2001 and MAR 2008. General firm characteristics are annual but firm level external trade statistics are monthly. The trade statistics are destination specific and include 8-digit CN product classification, value, and units. ${ }^{14}$ Thus, I compute unit values to proxy for free on board (FOB) export prices, as opposed to import prices that include cost, insurance and freight (CIF). Clearly, using export prices is less problematic than using import prices that contain elements that blur the pass-through picture and thus demanding usage of different controls.

\footnotetext{
${ }^{13}$ I have also computed a sample that only uses the firm's single best selling product throughout the sample period. Results are similar to those presented in the paper.

${ }^{14} \mathrm{CN}$ is the Combined Nomenclature: The first six diggits are consistent with HS6, the last two are free of choice for the reporting country if the reporting country does not follow the European standard.
} 


\begin{tabular}{|c|c|c|c|c|}
\hline & Obs. & Mean & Median & Std.dev \\
\hline \multicolumn{5}{|l|}{ Annual data (2002-2007) } \\
\hline \multicolumn{5}{|l|}{ Full sample } \\
\hline \multicolumn{5}{|l|}{ Firms } \\
\hline \# employees & 1871 & 296 & 106 & 828 \\
\hline export share of revenue & 7014 & 0,60 & 0,61 & 0,28 \\
\hline \multicolumn{5}{|l|}{ Exports } \\
\hline log unit values & 68050 & 5,00 & 4,81 & 1,97 \\
\hline log value of exports & 68050 & 13,11 & 13,24 & 2,49 \\
\hline \multicolumn{5}{|l|}{ High-income country sample } \\
\hline \multicolumn{5}{|l|}{ Firms } \\
\hline \# employees & 1854 & 261 & 98 & 747 \\
\hline export share of revenue & 6925 & 0,60 & 0,61 & 0,27 \\
\hline \multicolumn{5}{|l|}{ Exports } \\
\hline log unit values & 33040 & 4,94 & 4,74 & 1,92 \\
\hline log value of exports & 33040 & 13,43 & 13,60 & 2,44 \\
\hline \multicolumn{5}{|l|}{ Monthly data (2001-2008) } \\
\hline \multicolumn{5}{|l|}{ Full sample } \\
\hline \multicolumn{5}{|l|}{ Firms } \\
\hline \# employees & 2567 & 335 & 102 & 971 \\
\hline export share of revenue & 11470 & 0,63 & 0,65 & 0,27 \\
\hline \multicolumn{5}{|l|}{ Exports } \\
\hline log unit values & 653604 & 5,05 & 4,86 & 2,02 \\
\hline log value of exports & 653604 & 11,83 & 11,90 & 2,03 \\
\hline \multicolumn{5}{|l|}{ High-income country sample } \\
\hline \multicolumn{5}{|l|}{ Firms } \\
\hline \# employees & 2538 & 278 & 89 & 844 \\
\hline export share of revenue & 11324 & 0,63 & 0,65 & 0,27 \\
\hline \multicolumn{5}{|l|}{ Exports } \\
\hline log unit values & 355961 & 4,99 & 4,79 & 1,99 \\
\hline log value of exports & 355961 & 11,95 & 12,02 & 1,99 \\
\hline
\end{tabular}

Table 1: Firm level data descriptives

The 27 countries included in the data set are listed in appendix B. Among these countries are 14 major non-euro Danish export destinations ${ }^{15}$ (see Table 2). Denmark participates in the European Exchange Rate Mechanism (ERM II) with a central rate of DKK 746.038 per $€ 100$. The system allows members to deviate by ${ }_{-}^{+} 15 \%$, however, Denmark follows an agreement with the European Central Bank and the euro area members on a narrower fluctuation band of ${ }_{-}^{+} 2.25 \%$ (Danmarks Nationalbank). The analysis in this paper does not cover trade with the euro area. ${ }^{16}$

About half of Danish exports in 2006 was manufacturing exports. Half of that export went to non-euro destinations. Thus, non-euro exports made up about a quarter of Danish exports, constituting a cornerstone of Danish exports. If exporters indeed do react considerably to exchange rates, we have identified exchange rates as a likely source for short run aggregate export volatility that is not related to product market shocks.

\footnotetext{
${ }^{15}$ Constituting $44 \%$ of manufacturing exports (Statistics Denmark, see table 2)

${ }^{16}$ See figure B4 in the appendix for graphical inspection of the DKK-EUR relationship.
} 


\begin{tabular}{|c|c|c|c|}
\hline Country & DKR & EUR & Share \\
\hline Germany & 45.851 & 6.163 & 16.6 \\
\hline Great Britain* & 23.986 & 3.224 & 8.7 \\
\hline Sweden* & 23.355 & 3.139 & 8.4 \\
\hline USA $^{*}$ & 22.196 & 2.983 & 8.0 \\
\hline France & 12.885 & 1.732 & 4.7 \\
\hline Norway* & 12.378 & 1.664 & 4.5 \\
\hline Netherlands & 10.516 & 1.413 & 3.8 \\
\hline Italy & 9.811 & 1.319 & 3.5 \\
\hline Spain & 7.683 & 1.033 & 2.8 \\
\hline Japan* & 7.547 & 1.014 & 2.7 \\
\hline Poland* & 5.688 & 765 & 2.1 \\
\hline Rusia* & 5.376 & 723 & 1.9 \\
\hline Finland & 4.713 & 634 & 1.7 \\
\hline China* & 4.163 & 560 & 1.5 \\
\hline Belgium & 3.849 & 517 & 1.4 \\
\hline Ireland & 3.634 & 488 & 1.3 \\
\hline Czech Rep* & 3.523 & 474 & 1.3 \\
\hline Australia* & 3.109 & 418 & 1.1 \\
\hline Switzerland* & 2.640 & 355 & 1.0 \\
\hline Greece & 2.580 & 347 & 0.9 \\
\hline Canada* & 2.424 & 326 & 0.9 \\
\hline Austria & 2.335 & 314 & 0.8 \\
\hline Korea* & 2.306 & 310 & 0.8 \\
\hline Hungary* & 1.520 & 204 & 0.5 \\
\hline Turkey* & 1.502 & 202 & 0.5 \\
\hline Total Danish manufacturing trade & 276.667 & 37.186 & \\
\hline Top 25 share of manufacturing trade & & & 81.5 \\
\hline Non-euro share of manufacturing & & & 46.12 \\
\hline Top 25 manufacturing share of total trade & & & 50.87 \\
\hline
\end{tabular}

Table 2: Top 25 manufacturing export destinations

Compared to analyzing annualized data, this product detail at the monthly level brings us very close to the transaction level decisions. Matching this with monthly fluctuations in exchange rates, clearly brings us closer to a mapping between foreign exchange rates and productdestination-time specific pricing decisions.

Monthly foreign nominal exchange rates (NER) are from the Federal Reserve Bank of New York. Real exchange rates (RER) are CPI-deflated nominal rates. In the short run, fluctuations in the nominal exchange rate transfer to the real exchange rate. In the very short run (i.e. month-to-month) one can assume for country c that $\varepsilon_{c}=E_{c} \bar{P}_{c}$ where $\bar{P}_{c}$ is the fixed, relevant, relative price index between Denmark and country $c$, and $\varepsilon$ is the real exchange rate. Thus a shock to the nominal exchange rate $E$ changes the real exchange rate one-to-one and thus affects the decisions of the firm in (almost) the same way. The assumption that the real and the nominal exchange rates are highly correlated is consistent with empirical findings (see e.g. Kollman, 1997). In the results I primarily refer to estimations using the real exchange rate but 
I also show results from the nominal exchange rate. ${ }^{17}$

Appendix B contains graphs of selected exchange rates. To ease the graphical comparison of exchange rates in appendix B, I clear unit differences in exchange rates by computing the demeaned exchange rate, $\widetilde{e_{c t}}$, between DKK and each foreign currency of country $c$ at time $t$ as $\widetilde{e_{c t}}=\frac{e_{c t}}{e_{c}}$ where $e_{c t}$ is the average exchange rate in month $t$, and $\overline{e_{c}}$ is the sample time average. I also use this demeaned exchange rate in the estimations, but it has no impact on the analyses. Exchange rates, $e_{c t}$, are denoted in foreign currency per Danish Krone. If $e_{c t}$ increases by $10 \%$, $\widetilde{e_{c t}}$ also increases by $10 \%$ constituting a $10 \%$ appreciation of the Danish Krone.

\section{Estimation}

I use two main estimation equations to estimate export price elasticities. Equation (1) is similar to Berman, Martin \& Mayer (2012) and I use it for estimations involving annual data as well as monthly data:

$$
\ln U V_{i j c t}=\beta_{0}+\gamma \ln \widetilde{e_{c t-l}}+\eta_{t}+\mu_{i j c}+\varepsilon_{i j c t}
$$

The dependent variable $\ln U V_{i j c t}$ is $\log$ of the unit value, an approximation for FOB export prices. The explanatory exchange rate variable $\ln \widetilde{e_{c, t-l}}$ includes a certain lag of the exchange rate where $l=\{0,1, . ., 12)$ indicates either the lag in years or months ${ }^{18}$ depending on the particular estimation carried out. The resulting estimates of $\gamma$ are directly interpretable as implied price elasticities with respect to the exchange rate. Exchange rates are commonly ${ }^{19}$ used as exogenous variation in firm-level studies for many purposes other than PTM and exchange rate passthrough, because exchange rate shocks are assumed to be orthogonal to other macroeconomic shocks that hit firms.

I use pooled OLS with dummies to capture fixed effects, so the estimate of $\gamma$ is the dummy variable estimator (i.e. a fixed effects within-regression). The variable indices are firm (i), product $(\mathrm{j})$, destination country $(\mathrm{c})$, and time (t). I control for each year or month in the sample $\left(\eta_{t}\right)$ and add firm-product-destination fixed effect $\left(\mu_{i j c}\right)$ to catch firm-specific effects for the individual firm's destination-specific product market. Industry fixed effect are not included

\footnotetext{
${ }^{17}$ For simplicity I refer to the exchange rate in the remaining part of this section without distiguishing between the nominal and the real exchange rate.

${ }^{18}$ Note that $l=0$ in the estimations that use annual data because I use same-year-average exchange rate. In the estimations that use monthly data, I always use minimum one month lagged exchange rate.

${ }^{19}$ See fx. Greenaway, Kneller \& Zhang (2008), Verhoogen (2008), Hummels, Jorgensen, Munch \& Xiang (2010, on Danish annual firm-level data), and Brambilla, Lederman \& Porto (2010)
} 
as they introduce singularity.

From theory we know that an exporter practicing PTM will decrease its home currency price-in order to stay competitive in a foreign market-following an appreciation of its currency. So we expect $\gamma<0$. If $|\gamma|<1$ the exporter will lower the price by less than one-to-one, implying that the foreign importer will experience a rise, $d p_{t}^{M}=d e_{c, t-l} \cdot(1-|\gamma|)$, in the import price measured in the foreign currency at time t. The rise in the import price will thus a be lower percent increase than the the percent change in the exchange rate.

As discussed above, I wish to make the distinction between SRPTM and LRPTM. I can make this distinction using short-run data like monthly data. SRPTM tells us when and by how much an exporter changes its price in response to exchange rate fluctuation in the short run, while LRPTM tells us what the exporter's general pricing strategy is in response to trend movements of the exchange rate. I use a common definition of $\mathrm{LRPTM}^{20}$, defined as the sum of the coefficients of the lags across time. The estimation equation is similar to the long-run exchange rate pass-through specification by Gopinath \& Itskhoki $(2010):^{21}$

$$
\ln U V_{i j c t}=\beta_{0}+\sum_{l=1}^{12}\left(\gamma_{l} \cdot \ln \widetilde{e_{c, t-l}}\right)+\eta_{t}+\mu_{i j c}+\varepsilon_{i j c t}
$$

I use equation (2) in two different ways:

The first way is for estimating LRPTM, which is calculated as the sum of the coefficients $\sum_{l=1}^{12} \gamma_{l}$ for all 12 lags of the exchange rate. The second way is to estimate restricted versions by testing the exclusion of both single and multiple lags from the LRPTM-estimates. This I do in search of particular lagged responses for example within industries that may suggest differences across industries. Based on these restricted number of lags I then estimate SRPTM according to equation 1.

\section{Results}

This section first presents results from using the annual data to estimate average PTM in subsection 5.1. These estimates compare with estimates from French firm level studies using annual data and similar technique (Berman, Martin \& Mayer, 2012). The estimates from the annual Danish data then serve as reference estimates of the level PTM, that the literature has

\footnotetext{
${ }^{20}$ See e.g. Gopinath \& Itskhoki (2010) and Campa \& Goldberg (2005).

${ }^{21}$ While they trail back two years of monthly lags, I stick to one year in this paper. The reason is the comparison with annual estimates.
} 
so far been able to offer. Subsection 5.2 then presents results using the monthly data. That subsection will particularly highlight the information gained regarding differences in SRPTM and LRPTM.

5.1. Estimates of PTM Using Annual Data. Estimates by Berman, Martin \& Mayer (2012) on French firm level annual data suggest that average PTM is low, around 10-12\%. Column 1 in Table 3 presents average estimates of PTM using the Danish firm level annual data. Whether we use nominal exchange rates or real exchange rates has little impact on the estimate. The conclusion drawn is that using annual data, we find a bit higher base estimates of aggregate PTM on Danish firm level data compared to French data. ${ }^{22}$ Judging from these annual estimates, Danish exporters lower export prices by $1.4 \%$ on average when facing an exchange rate appreciation of $10 \%$. Columns 2-4 show estimates split on top level industry categories according to NACE classification Rev. 1.1. Clearly, the impression from these results is that the aggregate estimate in column 1 is the result of considerable variation across industries. Multiple explanations exists since firms in different industries face different challenges such as timing of production and differences in how to operate in the market, ${ }^{23}$ or level of competition (possibly due to selection issues related to barriers of entering a market in the first place). Concrete examples will be discussed in section 5.2.

(1)

(2)

(3)

(4)

\begin{tabular}{|c|c|c|c|c|}
\hline Dependent variable & \multicolumn{4}{|c|}{ log unit value } \\
\hline \multicolumn{5}{|l|}{ Nominal exchange rate (NER) } \\
\hline \multirow[t]{2}{*}{$\log (\mathrm{NER})$} & $-0,16^{c}$ & $-0,13^{c}$ & $-0,16$ & $-0,19^{c}$ \\
\hline & $(0,07)$ & $(0,06)$ & $(0,11)$ & $(0,09)$ \\
\hline $\mathrm{R}^{2}$ & 0,97 & 0,98 & 0,96 & 0,97 \\
\hline No. observations & 68050 & 8858 & 39273 & 19919 \\
\hline \multicolumn{5}{|l|}{ Real exchange rate (RER) } \\
\hline \multirow[t]{2}{*}{$\log (\mathrm{RER})$} & $-0,14^{c}$ & $-0,17^{c}$ & $-0,09$ & $-0,21^{a}$ \\
\hline & $(0,07)$ & $(0,07)$ & $(0,09)$ & $(0,05)$ \\
\hline $\mathrm{R}^{2}$ & 0,97 & 0,98 & 0,96 & 0,97 \\
\hline No. observations & 68050 & 8858 & 39273 & 19919 \\
\hline Sample (NACE industry category) & all & $\mathrm{NACE}=1$ & $\mathrm{NACE}=2$ & $\mathrm{NACE}=3$ \\
\hline
\end{tabular}

Table 3: Pricing-to-market - annual data

\footnotetext{
${ }^{22}$ Note that estimates using Danish data are only significant at the 10 percent level. French estimates are more significant (see Berman, Martin \& Mayer, 2012).

${ }^{23}$ For example off-the-shelf products such as socks compared to products produced after contracts are settled such as new turbines for a factory.
} 
The extent of PTM also varies across markets. Singling out high-income destination markets, we see that PTM is particularly strong on high-income destination markets (see table 4, columns 3 and 4) compared to the full sample of export markets (columns 1 and 2). In other words: PTM on low-income markets pulls down average PTM estimates. ${ }^{24}$ That PTM is stronger on high-income markets makes sense and is in-line with theories of more local-currency-pricing in the stable monetary high-income economies (see e.g. Engel \& Devereux, 2001, and Bacchetta \& Wincoop, 2005). On large and well-established markets ${ }^{25}$ the presence of more varieties implies fiercer competition, and thus a firm must adjust prices to stay in the market in response to exchange rate movements (see Berman, Martin \& Mayer, 2012, and Meltitz \& Ottaviano, 2008).

$$
\text { (1) }
$$

(2)

(3)

(4)

\begin{tabular}{lrrrr}
\hline Dependent variable & \multicolumn{5}{c}{ log unit value } \\
\hline \multicolumn{1}{l}{ log(exchange rate) } & $-0,16^{c}$ & $-0,14^{c}$ & $-0,25^{\mathrm{b}}$ & $-0,20 \mathrm{~b}$ \\
& $(0,07)$ & $(0,07)$ & $(0,07)$ & $(0,07)$ \\
$\mathrm{R}^{2}$ & 0,97 & 0,97 & 0,97 & 0,97 \\
No. observations & 68050 & 68050 & 33040 & 33040 \\
\hline Sample (markets) & all & all & high income & high income \\
Exchange rate used & nominal & real & nominal & real \\
\hline Source: Statistics Denmark, firm level external trade statistics, own calculations
\end{tabular}

Notes: Significance levels are 1, 5, 10 per cent $(a, b, c)$.

Table 4: Pricing-to-market - annual data

We now turn to the use of monthly data to see what we gain from using monthly data compared to using annual data.

5.2. Estimates of PTM Using Monthly Data. The analysis of PTM using monthly data will be disaggregated in the following four ways: First, the time dimension by going from annual to monthly observations of firm level trade. Second, within-industry PTM estimates. Third, separate high-income markets ${ }^{26}$ from the full sample. Fourth and finally, separate SRPTM from LRPTM.

Because this paper stresses the comparison of PTM estimates from annual data and monthly data, I use up to twelve monthly lags of the exchange rate to investigate whether this dynamic approach adds valuable information compared to the annual, average exchange rate used to find

\footnotetext{
${ }^{24}$ In fact, for some low-income countries individually, PTM results are inconclusive.

${ }^{25}$ The term is used loosely here. This could be a large economy such as Great Britain or an advanced but poorer economy like Korea, but it could also be a smaller economy with strong purchasing power, such as Norway, Sweden or New Zeeland.

${ }^{26}$ See table A.1 in the appendix. $78 \%$ of full sample trade flows are preserved in the restricted sample of high-income markets.
} 
annual estimates. This approach finds support in Campa \& Goldberg (2005). ${ }^{27}$ Adding all twelve coefficients gives an estimate of LRPTM. ${ }^{28}$

Aggregate results and market type distinction. I start the analysis of the short-run data by estimating industry-aggregate LRPTM for all markets and for high-income markets. I then test the exclusion of all lags, but the first, jointly. They are all accepted, and I then estimate SRPTM based on the first lag only.

(1)

(2)

(3)

\begin{tabular}{|c|c|c|c|c|}
\hline \multirow{2}{*}{$\frac{\text { Dependent variable }}{\log \left(\text { exchange rate }_{-1}\right)}$} & \multicolumn{4}{|c|}{ log unit value } \\
\hline & $\begin{array}{r}-0,18^{a} \\
(0,02)\end{array}$ & $\begin{array}{r}-0,18{ }^{a} \\
(0,02)\end{array}$ & $\begin{array}{c}-0,311^{a} \\
(0,02)\end{array}$ & $\begin{array}{r}-0,299^{a} \\
(0,03)\end{array}$ \\
\hline LRPTM & $-0,17$ & $-0,18$ & $-0,28$ & $-0,26$ \\
\hline $\mathrm{R}^{2}$ & 0,91 & 0,91 & 0,92 & 0,92 \\
\hline No. observations & 653604 & 653604 & 355961 & 355961 \\
\hline Sample (markets) & all & all & high income & high income \\
\hline Exchange rate used & nominal & real & nominal & real \\
\hline \multicolumn{5}{|c|}{$\begin{array}{l}\text { Source: Statistics Denmark, firm level external trade statistics, own calculations } \\
\text { Notes: Significance levels are } 1,5,10 \text { per cent }(a, b, c) \text {. LRPTM is the sum of the } \\
\text { coefficients of exchange rates in } t-1, t-2, . ., t-12 \text {, thus trailing back the cummulated } \\
\text { exchange rate response one year. All LRPTM-regressions pass joint significance tests } \\
\text { of the coeffecients. }\end{array}$} \\
\hline
\end{tabular}

Table 5: Long Run Pricing-to-market - monthly data

Table 5 compares estimates of LRPTM and the first, single, monthly lag using both the nominal and the real exchange rate as explanatory variables. Not surprisingly at this level of frequency, PTM estimates using the nominal exchange rate and the real exchange rate, respectively, are similar. Focusing on the short-run estimate ${ }^{29}$ based on the real exchange rate suggests that average PTM is higher than annual estimates suggest. Furthermore, at this industry-aggregate level, the short-run and long-run estimates coincide for the whole sample. For high-income markets a small difference appears, however I cannot tell whether the difference is significant.

Comparing the overall estimates (columns 1 and 2) with the estimates from high-income markets (columns 3 and 4) in table 5, we see that PTM is much stronger in high-income markets with LRPTM at $26 \%$ or higher, and SRPTM at $29 \%$ and higher. This is consistent with Drozd \& Nosal's (2012) reciprocal prediction of lower short-run than long-run pass-through onto import

\footnotetext{
${ }^{27}$ They add up to four lags of the exchange rate in their analysis that uses quarterly data.

${ }^{28}$ I have also tried adding up to 24 for lags, just as Gopinath \& Itskhoki (2010) do when determining LongRun-Pass-Through. This does not add value to the determination of LRPTM.

${ }^{29}$ By picking the first lag as a result of exclusion testing.
} 
prices. Note also that the differences in estimates between those from high-income markets are higher when we use monthly data (26-29\% for RER) compared to when we use annual data $(20 \%$ for RER $) .{ }^{30}$

\begin{tabular}{|c|c|c|c|c|c|c|c|c|c|c|}
\hline \multicolumn{2}{|c|}{ Dependent variable } & \multicolumn{3}{|c|}{ log unit value } & \multicolumn{4}{|c|}{ log unit value } & \multirow[b]{2}{*}{ \# firms } & \multirow[b]{2}{*}{ \# products } \\
\hline Nace code & NACE description & LRPTM & $\mathbf{R}^{2}$ & \# Obs. & RER-lag & SRPTM & $\mathbf{R}^{2}$ & \# obs. & & \\
\hline 15 & Manufacture of food products and beverages & $-0,22$ & 0,92 & 34740 & 1 & $\begin{array}{c}-0,19^{a} \\
(0,04)\end{array}$ & 0,92 & 39639 & 270 & 1005 \\
\hline 17 & Manufacture of textiles & $-0,05$ & 0,87 & 10958 & 1 & $\begin{array}{c}-0,26^{b} \\
(0,12)\end{array}$ & 0,87 & 12502 & 93 & 580 \\
\hline 21 & Manufacture of pulp, paper and paper products & $-0,12$ & 0,90 & 7529 & 1 & $\begin{array}{r}-0,11 \\
(0,19)\end{array}$ & 0,90 & 8461 & 54 & 272 \\
\hline 22 & Publishing, printing and reproduction of recorded media & $-0,16$ & 0,88 & 4749 & 1 & $\begin{array}{c}-1,09^{a} \\
(0,34)\end{array}$ & 0,88 & 5160 & 61 & 187 \\
\hline 24 & Manufacture of chemicals and chemical products & $-0,43$ & 0,96 & 20061 & 1 & $\begin{array}{c}-0,59^{a} \\
(0,10)\end{array}$ & 0,96 & 22889 & 139 & 786 \\
\hline 25 & Manufacture of rubber and plastic products & $-0,22$ & 0,88 & 29436 & 3 & $\begin{array}{c}-0,33^{a} \\
(0,10)\end{array}$ & 0,88 & 29824 & 181 & 805 \\
\hline 26 & Manufacture of other non-metallic mineral products & 0,09 & 0,96 & 6803 & 1 & $\begin{array}{c}-0,266^{c} \\
(0,14)\end{array}$ & 0,96 & 7828 & 65 & 442 \\
\hline 27 & Manufacture of basic metals & $-0,21$ & 0,92 & 6814 & 5 & $\begin{array}{r}-0,13 \\
(0,14)\end{array}$ & 0,92 & 6898 & 59 & 407 \\
\hline 28 & $\begin{array}{l}\text { Manufacture of fabricated metal products, except machinery and } \\
\text { equipment }\end{array}$ & 0,00 & 0,86 & 32533 & 2 & $\begin{array}{r}-0,03 \\
(0,10)\end{array}$ & 0,86 & 37050 & 279 & 1253 \\
\hline 29 & Manufacture of machinery and equipment n.e.c. & $-0,17$ & 0,77 & 100264 & 11 & $\begin{array}{c}-0,19^{a} \\
(0,06)\end{array}$ & 0,78 & 105734 & 567 & 1938 \\
\hline 30 & Manufacture of office machinery and computers & $-0,37$ & 0,75 & 4345 & 4 & $\begin{array}{c}-0,44^{\circ} \\
(0,23)\end{array}$ & 0,75 & 4784 & 29 & 257 \\
\hline 31 & Manufacture of electrical machinery and apparatus n.e.c. & $-0,13$ & 0,85 & 18470 & 1 & $\begin{array}{r}-0,11 \\
(0,10)\end{array}$ & 0,85 & 21407 & 142 & 828 \\
\hline 32 & $\begin{array}{l}\text { Manufacture of radio, television and communication equipment and } \\
\text { apparatus }\end{array}$ & $-0,69$ & 0,86 & 11114 & 3 & $\begin{array}{c}-1,12^{b} \\
(0,51)\end{array}$ & 0,86 & 10722 & 83 & 491 \\
\hline 33 & $\begin{array}{l}\text { Manufacture of medical, precision and optical instruments, watches } \\
\text { and clocks }\end{array}$ & $-0,06$ & 0,84 & 34003 & 1 & $\begin{array}{c}-0,38^{a} \\
(0,09)\end{array}$ & 0,84 & 38877 & 167 & 849 \\
\hline 34 & Manufacture of motor vehicles, trailers and semi-trailers & $-0,42$ & 0,85 & 8012 & 1 & $\begin{array}{c}-0,35^{\circ} \\
(0,16)\end{array}$ & 0,85 & 9175 & 53 & 364 \\
\hline 35 & Manufacture of other transport equipment & $-0,57$ & 0,88 & 4915 & 1 & $\begin{array}{c}-0,68^{\circ} \\
(0,34)\end{array}$ & 0,88 & 5020 & 68 & 508 \\
\hline 36 & Manufacture of furniture; manufacturing n.e.c. & 0,04 & 0,91 & 32210 & 1 & $\begin{array}{c}-0,14^{b} \\
(0,05)\end{array}$ & 0,91 & 36147 & 223 & 559 \\
\hline \multicolumn{11}{|c|}{ PTM (based on selected sectors above) } \\
\hline \multicolumn{2}{|c|}{ Mean (weighted) } & $-0,16$ & & & & $-0,27$ & & & & \\
\hline \multicolumn{2}{|c|}{ Mean (unweighted) } & $-0,22$ & & & & $-0,38$ & & & & \\
\hline \multicolumn{2}{|l|}{ Median } & $-0,17$ & & & & $-0,26$ & & & & \\
\hline
\end{tabular}

Table 6: Industry specific estimations of Pricing-to-market - using monthly data

Industry variation. So far I have shown that disaggregating the time-dimension of PTM estimates delivers higher PTM estimates than estimations from annual data. Furthermore, we also know that PTM is particularly pronounced on high-income markets.

I now decompose the estimates on two-digit NACE-level industries for high-income markets. Table 6 presents the resulting estimates of LRPTM and prevailing lags after restriction tests ${ }^{31}$ as a measure of the extent of SRPTM. Certain sectors have been left out of the table. Common for these sectors is that the panel consists of either few firms, few observations, or both. The table reads as follows: The left hand side columns contain results from estimation of LRPTM within

\footnotetext{
${ }^{30}$ See column 4 of tables 4 and 5 , respectively.

${ }^{31}$ Every SRPTM estimation is different. Most contain a single lag, others contain a restricted set of lags where one lag becomes significant.
} 
each 2-digit nace industry code. The right hand side columns contain estimates of SRPTM. RER-lag gives the significant lag number (e.g. a "1" reads SRPTM prevails at the one month lag, "11" at the 11 months lag, etc.). In the column to the right of RER-lag one finds the associated value.

Three key points from table 6 are particularly interesting: First, SRPTM is higher than LRPTM supporting the theoretical framework Drozd \& Nosal (2012) and in-line with the empirical results of Campa \& Goldberg (2005)-both discussed earlier. Second, firms in most sectors respond to exchange rates in the very short run, but some react in the medium-/short-run (3-5 months) and in a single sector firms reacts well in advance of the shipping date and thus more discretionary. Third and final, PTM varies considerably across sectors - from zero to $69 \%$ in the long run, and from zero to complete PTM in the short-run. ${ }^{32}$ These results in general suggest that average PTM is low in the long-run, about (15-20\%) but the variation across sectors is quite wide. Of the estimations presented above, significant findings of industry level PTM cover $81 \%$ of all observations and $79 \%$ of all firms (implying that not all firms, but quite a significant share, price-to-market).

While average SRPTM is almost twice the size of LRPTM, the detailed picture is much more varying. In the sector Manufacture of textiles (Nace code 17), LRPTM is very low, 5\%, but 1-month-SRPTM at $26 \%$ is seven times higher. This reflects a sector in which short-term settlements dominate conduct of business. In the sector Manufacture of radio, television and communication equipment and apparatus (Nace code 32) firms are active in LRPTM and 3months-SRPTM. This indicates that firms settle contracts and payments with sellers at least three months in advance of the shipment. Firms in the sector Manufacture of machinery and equipment n.e.c. (Nace code 29) make price adjustments in response to the exchange rate well ahead of shipment. Evidence of SRPTM is weak and coincides with LRPTM. This makes sense. Firms in this sector produce heavy manufacturing equipment and production of such products are often made on specific orders and possibly tailored for the individual need of the customer, not on expected orders.

To sum up, the evidence from the estimations of PTM on the monthly firm level trade data suggest that a more accurate PTM measure compared to an annual estimate enhances the documentation of presence of PTM. Or equivalently: pass-through is lower than one can expect when estimating pass-through rates from annual data. We cannot rule out neither producer-

\footnotetext{
${ }^{32}$ Highest value is $112 \%$ which is close to (actually more than) a one-one reaction to the exchange rate.
} 
currency-pricing (complete pass-through or zero PTM) nor local-currency-pricing (zero passthrough or complete PTM) as Campa \& Goldberg (2005). Estimates vary across industries and these findings open up for further research on timing of production, negotiation of contracts and pricing strategies of firms in different industries.

\section{Conclusion}

Danish exporters price to market. Unlike other studies on pricing-to-market or exchange rate pass-through, I disaggregate the time-aggregate estimates that one gets from using annual data by making use of high-frequency firm-level export data. From this data I explore the heterogeneity across industries and market types as well as aspects of dynamic pricing-to-market. The resulting price elasticities to the exchange rate are based on information on the numerous short-run fluctuations that are aggregated away in the annual estimates.

Estimates in this paper show that the short-run average pricing-to-market in the manufacturing sector is $18 \%$. This compares with $14 \%$ using annual data. In-line with theoretical predictions pricing-to-market is higher on high-income-markets: $22 \%$ in the long-run and $38 \%$ in the short-run (un-weighted averages). Across industries pricing-to-market varies from zero to unity, implying that both producer-currency-pricing and local-currency-pricing occur in specific industries. Also in-line with theoretical predictions, Pricing-to-market is remarkably higher in the short-run compared to the long-run, underlining the belief that sellers fight for market shares in the short-run but in the longer run the market will expand and pricing strategies based on exchange rate fluctuations become less important. 


\section{Appendix A: Descriptive tables}

\begin{tabular}{lcc} 
Countries & High-income markets & G7 (non-euro) \\
\hline Australia & $\mathrm{x}$ & \\
Brazil & & $\mathrm{x}$ \\
Canada & $\mathrm{x}$ & \\
China & & $\mathrm{x}$ \\
Czech Republic & $\mathrm{x}$ & \\
Great Britain & $\mathrm{x}$ & $\mathrm{x}$ \\
Hong Kong & $\mathrm{x}$ & \\
India & $\mathrm{x}$ & \\
Japan & & \\
Korea & & \\
Malaysia & $\mathrm{x}$ & \\
Mexico & $\mathrm{x}$ & \\
New Zeeland & & \\
Norway & \\
Poland & $\mathrm{x}$ & \\
Rusia & & \\
Singapore & & \\
Slovakia & & \\
South Africa & & \\
Sri Lanka & $\mathrm{x}$ & \\
Sweden & $\mathrm{x}$ & \\
Switzerland & & \\
Taiwan & & \\
Thailand & & \\
Turkey & & \\
USA & & \\
Venezuela & & \\
\hline
\end{tabular}

Note: High-income markets are defined as having minimum $50 \%$ nominal GDP per capita relative to Denmark. Korea is also placed here arbitrarily due to membership of the OECD and the size of the economy. No non-high-income countries in the list are richer than Korea in nominal per capita GDP terms.

Source: World Bank

Table A1: The 27 countries/economic regions in the sample

\begin{tabular}{lcccccccccc} 
& \multicolumn{10}{c}{ Absolute percentage change of DKK-USD exchange rate } \\
\cline { 2 - 11 } & 10 & 9 & 8 & 7 & 6 & 5 & 4 & 3 & 2 & 1 \\
\hline Interval & & & & & & & & & & \\
1 month & 1 & 3 & 4 & 5 & 9 & 11 & 15 & 20 & 29 \\
3 months & & 3 & 8 & 10 & 14 & 15 & 18 & 25 & 27 & 29 \\
\hline
\end{tabular}

Source: New York Federal Reserve, own calculations

Table A2: Number of observed fluctuations in the DKK-USD exchange rate in 2004-2006 


\section{Appendix B: Graphical representation of exchange rates}

All currencies in the graphs are in nominal exchange rates and are denoted in foreign currency per DKK. They are expressed in terms of units relative to the sample time average (i.e. they fluctuate around 1 over the time span of the sample). Monthly exchange rates are averages of daily averages. Annual rates are simple averages of monthly averages. Source: Federal Reserve Bank of NewYork.

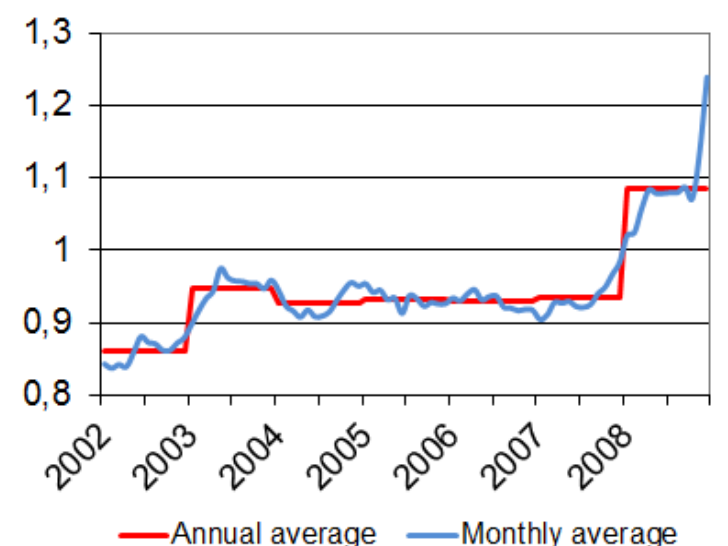

Figure C1: Great Britain

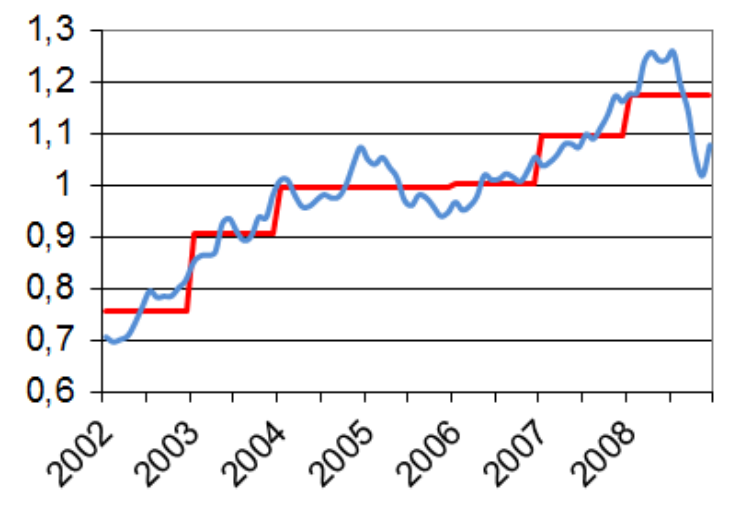

—Annual average —Monthly average

Figure C3: United States

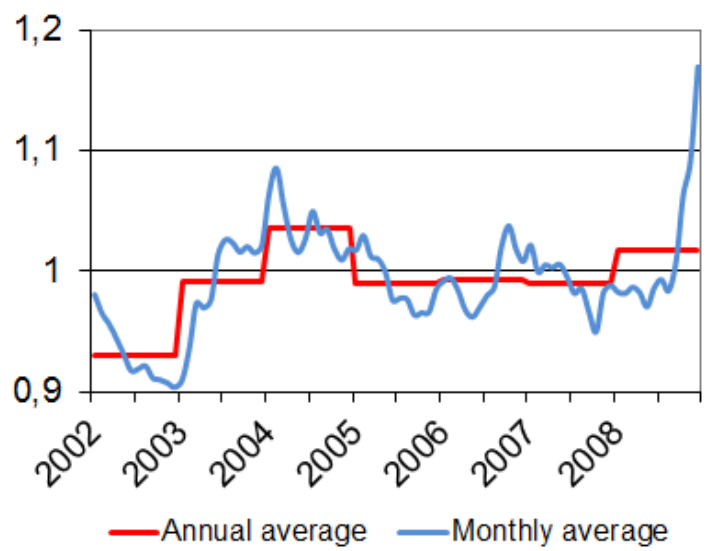

Figure C2: Norway

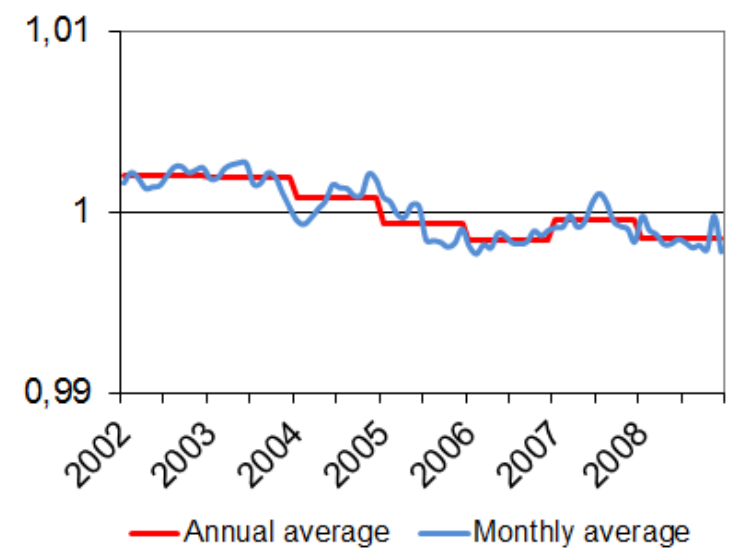

Figure C4: The Euro 


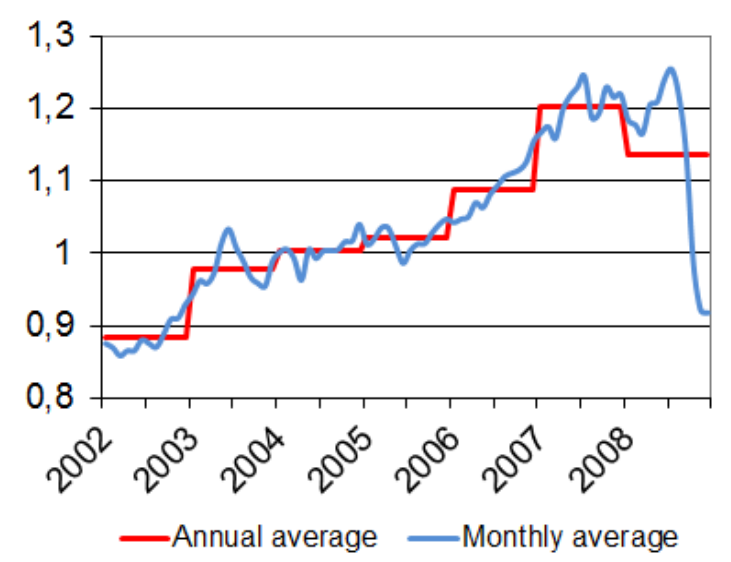

Figure C5: Japan

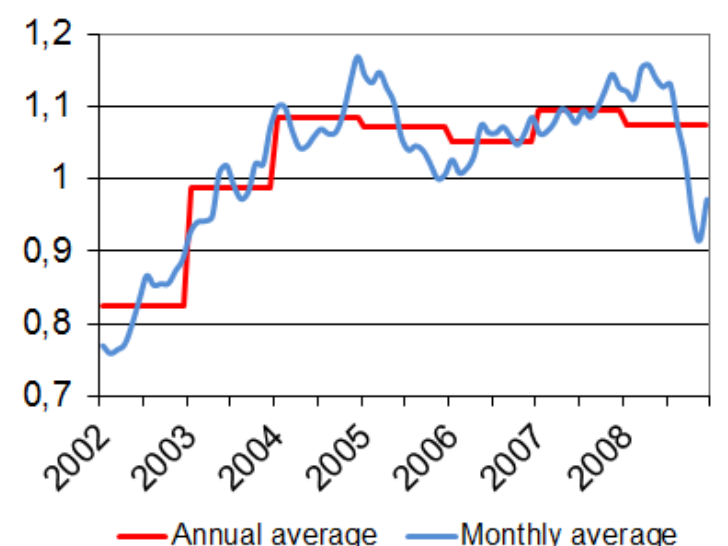

Figure C7: China

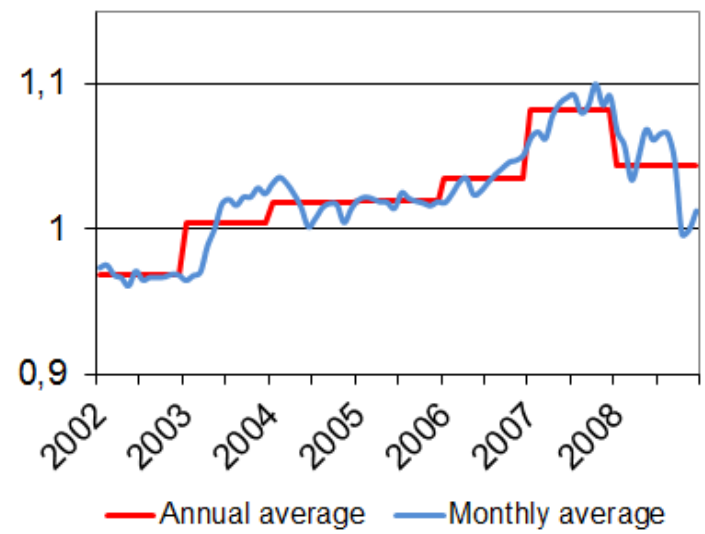

Figure C7: Switzerland

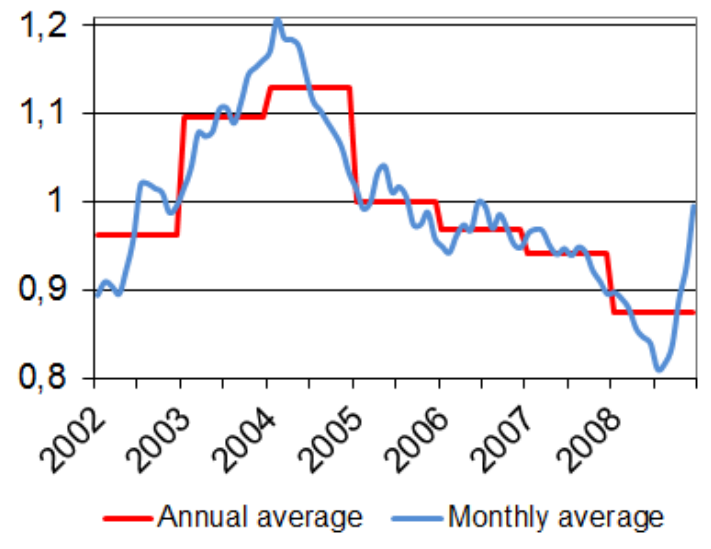

Figure C6: Poland

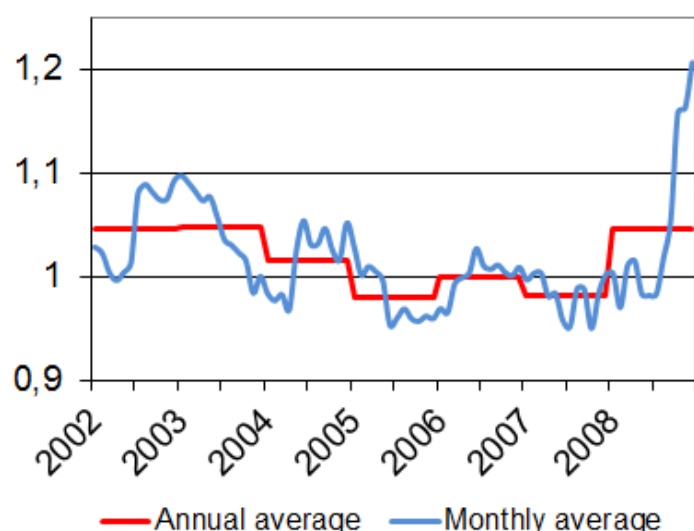

Figure C8: Austalia

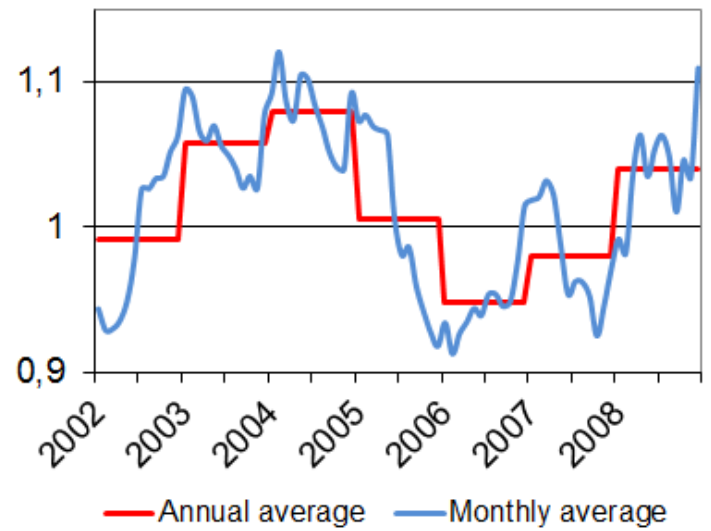

Figure C6: Canada 


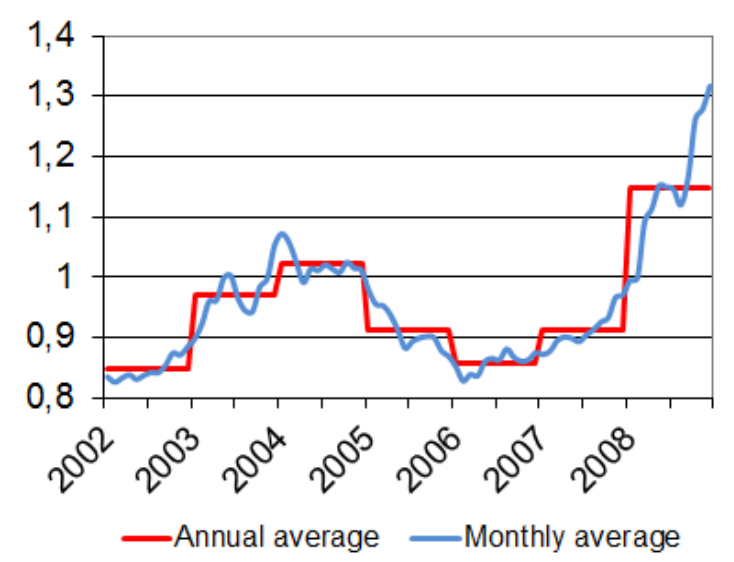

Figure C9: Rep. of Korea

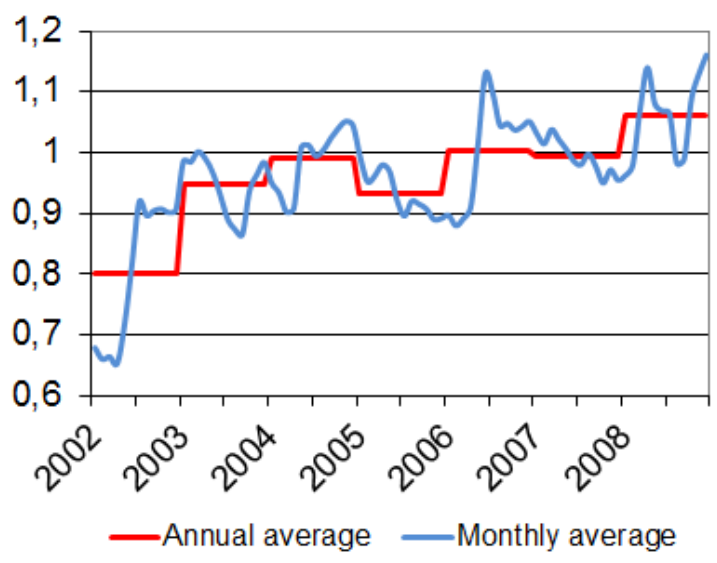

Figure C10: Turkey 


\section{REFERENCES}

[1] Atkeson, A. \& Burstein, A. (2008): Pricing-to-Market, Trade Costs, and International Relative Prices, American Economic Review 2008, 98:5, 1998-2031

[2] Bacchetta, P. \& van Wincoop. E (2005): A theory of the currency denomination of international trade, Journal of International Economics, Elsevier, vol. 67(2), pages 295-319, December

[3] Berman, N. Martin, P. \& Mayer, T. (2012): How do Different Exporters React to Exchange Rate Changes?, The Quarterly Journal of Economics (2012) 127(1): 437-492

[4] Brambilla, I. Lederman, D. \& Porto, G. (2010): Exports, Export Destinations, and Skills, NBER Working Paper 15995

[5] Auer, R. \& Chaney, T. (2008): Exchange Rate Pass-Through in a Competitive Model of Pricing-to-Market, Journal of Money, Credit and Banking, Volume 41, Issue Supplement s1, pages 151-175, February 2009

[6] Campa, J.M. \& Goldberg, L.S. (2005): Exchange Rate Pass-Through into Import Prices,The Review of Economics and Statistics, MIT Press, vol. 87(4), pages 679-690, December

[7] Chu,C.S., Leslie,P. \& Sorensen, A. (2011): Bundle-Size Pricing as an Approximation to Mixed Bundling, American Economic Review 101 (February 2011), p. 263-303

[8] Corsetti, G. \& Dedola, L. (2005), A Macroeconomic Model of International Price Discrimination", Journal of International Economics, 67(1), 129-155

[9] Devereux, M.B. \& Engel, C. (2001): Endogenous Currency of Price Setting in a Dynamic Open Economy Model, NBER Working Paper No. 8559, October 2001

[10] Drozd, L. \& Nosal, J.B. (2012): "Understanding International Prices: Customers as Capital." American Economic Review, 102(1): 364-95

[11] Eaton, J. and Kortum, S. (2002): Technology, Geography, and Trade, Econometrica, Econometric Society, vol. 70(5), pages 1741-1779, September 
[12] Engel, C. (2006): Equivalence Results for Optimal Pass-Through, Optimal indexing to Exchange Rates, and Optimal Choice of Currency, Journal of the European Economic Association, December 2006 4(6):1249-1260

[13] Feenstra, R.C., Gagnon, J.E., Knetter, M.M., 1996. "Market Share and Exchange Rate Pass-through in World Automobile Trade." Journal of International Economics, 40(1-2): $187-207$

[14] Goldberg, P.K. \& Knetter, M.M. (1997): Goods Prices and Exchange Rates: What Have We Learned?, Journal of Economic Literature, 35(3): 1243-72

[15] Gopinath, G. \& Itskhoki, O. (2010): Frequency of Price Adjustment and Pass-through, Quarterly Journal of Economics, 125(2), 675-727.

[16] Gopinath, Itskhoki \& Rigobon, R. (2007), Currency Choice and Exchange Rate PassThrough, NBER Working Paper 13432

[17] Gopinath, G. \& Rigobon, R. (2008), Sticky Borders, Quarterly Journal of Economics, $123(2), 531-575$.

[18] Greenaway, D., Kneller, R. \& Zhang, X. (2008): "Exchange Rates and Exports: Evidence from Manufacturing Firms in the UK," Discussion Papers 07/13, University of Nottingham, GEP

[19] Halpern, L. \& Koren, M. (2007): Pricing to Firm: an Analysis of Firm- and Productlevel Import Prices, Review of International Economics, Wiley Blackwell, vol. 15(3), pages $574-591,08$

[20] Hummels, D. Jorgensen, R., Munch, J.R. \& Xiang, C. (2010): The Wage and Employment Effects of Outsourcing: Evidence from Danish Matched Worker-Firm Data, working paper

[21] Knetter, M.M. (1993). "International Comparisons of Price-to-Market Behavior" American Economic Review, 83(3): 473-86.

[22] Kollman, R. (2001): The exchange rate in a dynamic optimizing current account model with nominal rigidities: a quantitative investigation, Journal of International Economics, Volume 55, Issue 2, December 2001, Pages 243-262 
[23] Lapham, B.J. (1995): A Dynamic General Equilibrium Analysis of Deviations from the Laws of One Price, Journal of Economic Dynamics and Control, 19(8): 1355-89.

[24] Melitz, M.J. (2003): The Impact of Trade on Intra-Industry Reallocations and Aggregate Industry Productivity, Econometrica, Econometric Society, vol. 71(6), pages 1695-1725, November

[25] Melitz, M.J. \& Ottaviano. G. (2008): Market Size, Trade, and Productivity, Review of Economic Studies (2008) 75, 295-316

[26] Verhoogen, E. (2008), Trade, Quality Upgrading, and Wage Inequality in the Mexican Manufacturing Sector," Quarterly Journal of Economics, Vol 123, No. 2, pp. 489-530 